\title{
Antimicrobial and Antibiofilm Potential of Acyclic Amines and Diamines against Multi-Drug Resistant Staphylococcus aureus
}

\section{OPEN ACCESS}

Edited by:

Noton Kumar Dutta Johns Hopkins University,

United States

Reviewed by:

Pankaj Kumar

Johns Hopkins School of Medicine,

United States

Divakar Sharma,

Interdisciplinary Biotechnology Unit,

Aligarh Muslim University, India

*Correspondence:

S. A. Princy

adlineprinzy@biotech.sastra.edu

Specialty section:

This article was submitted to Antimicrobials, Resistance and

Chemotherapy

a section of the journal

Frontiers in Microbiology

Received: 12 July 2017

Accepted: 31 August 2017 Published: 15 September 2017

Citation:

Kaur G, Balamurugan $P$, Vasudevan $S$, Jadav $S$ and

Princy SA (2017) Antimicrobial and Antibiofilm Potential of Acyclic

Amines and Diamines against

Multi-Drug Resistant Staphylococcus aureus. Front. Microbiol. 8:1767. doi: 10.3389/fmicb.2017.01767
Gurmeet Kaur, P. Balamurugan, Sahana Vasudevan, Saikiran Jadav and S. A. Princy*

Quorum Sensing Laboratory, Centre for Research in Infectious Diseases, School of Chemical and Biotechnology, SASTRA

University, Thanjavur, India

Multi-drug resistant Staphylococcus aureus (MDRSA) remains a great challenge despite a decade of research on antimicrobial compounds against their infections. In the present study, various acyclic amines and diamines were chemically synthesized and tested for their antimicrobial as well as antibiofilm activity against MDRSA. Among all the synthesized compounds, an acyclic diamine, (2,2'-((butane1,4-diylbis(azanediyl)bis(methylene))diphenol) designated as ADM 3, showed better antimicrobial activity (minimum inhibitory concentration at $50 \mu \mathrm{g} / \mathrm{mL}$ ) and antibiofilm activity $\left(\mathrm{MBIC}_{50}\right.$ at $\left.5 \mu \mathrm{g} / \mathrm{mL}\right)$. In addition, $A D M 3$ was capable of reducing the virulence factors expression (anti-virulence). Confocal laser scanning microscope analysis of the in vitro tested urinary catheters showed biofilm reduction as well as bacterial killing by ADM 3. On the whole, our data suggest that acyclic diamines, especially ADM 3 can be a potent lead for the further studies in alternative therapeutic approaches.

Keywords: biofilm, Staphylococcus aureus, multi-drug resistance, antibiofilm, diamines, antibacterial

\section{INTRODUCTION}

Staphylococcus aureus, a Gram-positive, facultative anaerobic cocci bacterium, is one of the most notorious pathogen, causing infections in humans. Their abilities to evade the host immune defense mechanism and resistance to the first and second generation antibiotics has made the pathogen a subject of interest in the scientific community (Fedtke et al., 2004). S. aureus is an opportunistic pathogen related to the various types of infectious diseases such as wound infections, catheterrelated bloodstream infections (CRBSI), musculoskeletal infections, toxic shock syndrome and, about $20 \%$ of population worldwide found to be the long-term carrier as a part of their normal flora (Kluytmans et al., 1997; Cole et al., 2001). Various factors associated with S. aureus such as virulence gene expressions, cell to cell signaling mechanism, inactivation of antibiotics, alteration in target sites, efflux pumps, and biofilm formation have led to the emergence of multi-drug resistant S. aureus (MDRSA) (Dinges et al., 2000; Becker et al., 2003; Zhu et al., 2008; Arya et al., 2011; Qayyum et al., 2016).

Planktonic microbes attach to a particular substratum and produce an anchoring polymer called as an extracellular polysaccharide (EPS) which leads to the formation of the multicellular microbial community known as biofilm (Flemming et al., 2007). The altered metabolic activity of the cells that are associated with biofilm formation have high rates of EPS production, activation of specific genes associated with biofilm formation and virulence, reduction in the growth rate than their planktonic 
counterparts (Flemming et al., 2007). Biofilm formation accounts for one of the major reasons for the emergence of multi-drug resistance (MDR) in various pathogenic microbes and is common in bacteria. In the biofilm mode of lifestyle, bacterial population acquires adaptation to tolerate and survive a wide range of diverse environmental stress such as scarce nutritional availability, antibiotics exposure, competition for survival in a multi-species environment (Parsek and Singh, 2003). The antibiotics tolerance ability of the biofilm cells complicates the treatment of various infections in humans, such as, cystic fibrosis, endocarditis, which includes biofilm formation on various biological implants such as, urinary catheters, heart catheters, various joint implants, and replacement of heart valves (Singh et al., 2000). Biofilms pose a threat to the human race because of their persistent nature and plays a major role in certain pathogenic infections (Singh et al., 2000; Ravichandiran et al., 2012; Arya and Princy, 2013; Otto, 2013). Several incidences have been reported with MDRSA strain infections such as CRBSI which is primarily due to either bacterial colonization on a device that may be intraluminal, i.e., formation of biofilm inside the lumen and causing persistent infection (Safdar and Maki, 2004). Similarly, musculoskeletal infections, wound infections, and nosocomial infections have also been reported by MDRSA which are very difficult to treat with the existing drugs (Bascones-Martinez et al., 2011; Abad et al., 2014; Vincze et al., 2014). Antibiofilm compounds are one such alternative option in the recent research focus. These small chemical ligands can independently inhibit bacterial biofilm or disrupt the biofilm matrix at the molecular level via, disturbing their metabolic pathways.

Medicinally important chemical compounds play a crucial role in treating various diseases which pose a threat to human survival at times. From our earlier reports, we have understood that acyclic amines could be promising leads against S. aureus, as one of our compounds (SarABI-12, 2-[(methylamino)methyl]phenol) was shown to have target specific interaction with the staphylococcal accessory regulator, SarA (Arya and Princy, 2013). In addition, our in vitro studies (Balamurugan et al., 2017) have confirmed the antibiofilm and anti-virulence properties against clinical S. aureus strains. The data also showed a significant reduction in the expression of SarA regulated virulence genes like $f n b A$, hla, and hld. It is also interesting to note that several researchers have reported the potential of cyclic amines and diamines to inhibit MDRSA, Enterococcus sp., Clostridium difficile, Escherichia coli, Aspergillus oryzae, Aspergillus niger (He et al., 2003; Abdel-Rahman et al., 2004; Hensler et al., 2006). The focus on the use of cyclic amines and diamines for antibacterial, antifungal and anti-proliferative activity has also been implicated (He et al., 2003; Juranić, 2014; Kazakova et al., 2014). Previous reports by Chtchigrovsky et al. (2013) shows the anti-proliferative activity of trans-Nheterocyclic carbene-amine-Pt(II) complexes. These complexes have the ability to bind to DNA, leading to intrastrand crosslinks between two adjacent guanines and minor interstrand cross links, resulting in DNA damage and cell death (Chtchigrovsky et al., 2013). Similarly, Subík et al. (1977) report the antibacterial and antifungal activity of amine oxides due to their ability to disorganize the cellular membranes leading to cidal effects.

It is expected that similar to cyclic amines, acyclic amines can also have medicinally important biological potentials, supported by our previous works (Arya and Princy, 2013; Balamurugan et al., 2017). Hence, we have investigated the antibiofilm and antibacterial properties of acyclic amines which have not yet been explored against pathogenic bacteria.

\section{MATERIALS AND METHODS}

\section{Synthesis of Acyclic Amine and Diamine Compounds}

The acyclic amines (AAM 1-5) and acyclic diamines (ADM 1-8) compounds were synthesized by a reductive amination process (Ramachandran et al., 2010). The synthesis process of acyclic amine and diamines is shown in the Figures 1A,B. For the synthesis of acyclic amines, a solution of the suitable aryl aldehyde $(10 \mathrm{mmol})$ and the suitable acyclic amine $(12 \mathrm{mmol})$ in methanol $(5 \mathrm{~mL})$ was stirred at room temperature for $1 \mathrm{~h}$. The reactants

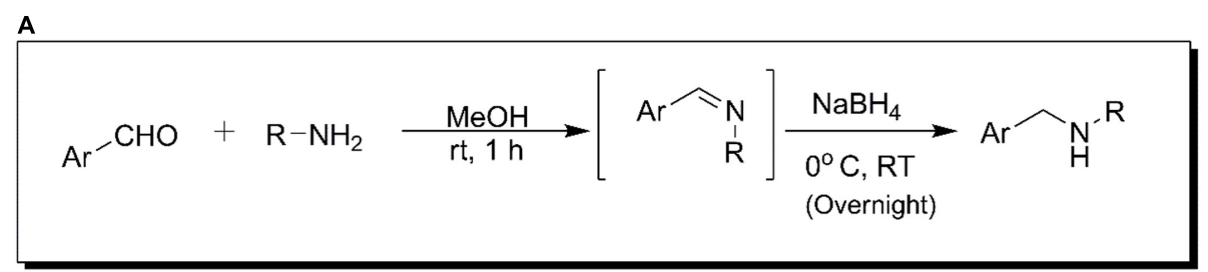

B

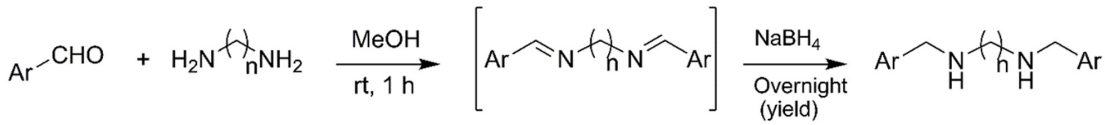

$$
\begin{aligned}
& n=2,3,4
\end{aligned}
$$

FIGURE 1 | Schematic representation of the reaction scheme for synthesis of (A) acyclic amines (B) acyclic diamines. 
were shown in Supplementary Table S1. The intermediate imines were reduced to the corresponding acyclic amines and diamines by the addition of sodium borohydride $(15 \mathrm{mmol})$ at the icecold condition. After stirring, the reaction mixture was incubated at room temperature overnight and further diluted with water and extracted thrice with dichloromethane. The mixed organic phases were dried with anhydrous sodium sulfate, evaporated to dryness under reduced pressure to obtain the acyclic amines and diamines. The structures of the synthesized products were confirmed by ${ }^{1} \mathrm{H}-\mathrm{NMR}$ spectroscopy.

\section{Bacterial Strains and Growth Conditions}

Clinical isolates of $S$. aureus were received from the rejected urinary catheters, JSS Medical College Mysore with prior approval from the Institutional Ethical Committee (IEC/JSSMC/PG/1050/2015-16). The strains were initially subjected to screening for MDR against the antibiotics: levofloxacin, ampicillin, ciprofloxacin, and methicillin. The S. aureus strain (MDRSA - QSL2040) that showed resistance to methicillin as well as other tested antibiotics (Table 1) was used as a test strain and the $S$. aureus (ATCC 25923) was used as reference strain (Kumar et al., 2013; Khatkar et al., 2014). These strains were cultured in the cation-adjusted Mueller-Hinton broth $(\mathrm{CAMHB})$ for the minimal drug dose response against the growth and bactericidal actions. For the biofilm assays, the tryptic soy broth (TSB) supplemented with $3 \% \mathrm{NaCl}$ and $0.5 \%$ glucose was used as the biofilm medium.

\section{Evaluation of Acyclic Amine and Diamine Compounds for MIC, MBC, and MBIC}

The minimum inhibitory concentration (MIC), the minimum bactericidal concentration (MBC), and the minimum biofilm inhibitory concentrations (MBIC) of the acyclic amines and diamines were determined according to the Clinical and Laboratory Standards Institute (CLSI) with slight modifications. The S. aureus clinical isolate (MDRSA - QSL2040) was grown overnight in TSB. The overnight culture was diluted 1:100 in

TABLE 1 | Antibiotic susceptibility profiling of the two strains used in the study.

\begin{tabular}{lll}
\hline Antibiotics & \multicolumn{2}{c}{ Strains used } \\
\cline { 2 - 3 } & ATCC 25923 & QSL2040 \\
\hline Levofloxacin & Sensitive & Resistant \\
Ampicillin & Sensitive & Resistant \\
Ciprofloxacin & Sensitive & Resistant \\
Methicillin & Sensitive & Resistant \\
Amoxicillin & Sensitive & Resistant \\
Penicillin & Sensitive & Resistant \\
Kanamycin & Sensitive & Resistant \\
Gentamicin & Sensitive & Resistant \\
Clindamycin & Sensitive & Intermediate \\
Vancomycin & Sensitive & Resistant \\
Oxacillin & Sensitive & Intermediate \\
\hline
\end{tabular}

Sensitivity/resistance pattern was concluded as per the CLSI guidelines. physiological saline and the bacterial suspensions were adjusted to a final inoculum size of $1 \times 10^{6}$ cells (Issam et al., 2015). The adjusted inoculum was added to the wells of a 96-well microtiter plate containing twofold serial dilutions of the compound (varying concentrations from 2 to $400 \mu \mathrm{g} / \mathrm{mL}$ as individual sets keeping different high concentrations) in CAMHB medium. The plates were incubated at $37^{\circ} \mathrm{C}$ for $24 \mathrm{~h}$. The setup was carried out as independent experiments (in triplicates) to calculate the effective concentration.

The optical density $\left(\mathrm{OD}_{600}\right)$ was read immediately after inoculation and again after $18 \mathrm{~h}$ of incubation at $37^{\circ} \mathrm{C}$, in a microtitre plate reader (iMark, Bio-Rad, Japan). The lowest concentration that inhibited growth when compared to the untreated control culture was taken as the MIC. Similarly, MBC was determined by counting the number of colonies $(\mathrm{CFU} / \mathrm{mL})$ after $24 \mathrm{~h}$ of incubation at $37^{\circ} \mathrm{C}$ and was defined as the lowest concentration at which the viable cells were reduced to a level by $\geq 90 \%$ in comparison to the untreated control cultures. All independent assays were carried out in triplicates.

For biofilm assay, diluted overnight culture (1:100) was inoculated in TSB and allowed to grow till it reached exponential growth phase $(5 \mathrm{~h})$. The culture was tested for $0.5 \mathrm{McF}$ arland unit and followed by inoculation along with varying concentrations of the compounds $(2-400 \mu \mathrm{g} / \mathrm{mL})$ in 96 -well microtitre plates. Plates were incubated for $24 \mathrm{~h}$ at $37^{\circ} \mathrm{C}$ without shaking. After incubation, the wells were washed twice with $200 \mu \mathrm{L}$ of phosphate-buffered saline (PBS) gently to remove the nonadherent cells. Adherent cells in the biofilm were fixed by adding $200 \mu \mathrm{L}$ of $100 \%$ methanol prior to staining with $200 \mu \mathrm{L}$ of $0.2 \%(\mathrm{w} / \mathrm{v})$ crystal violet $(\mathrm{CV})$ for $20 \mathrm{~min}$. The excess stain was washed twice with PBS and the plates were air dried. The bound $\mathrm{CV}$ in the air dried plates were eluted with $200 \mu \mathrm{L}$ of $33 \%$ acetic acid. The biofilm was quantitatively determined by measuring the absorbance at $\mathrm{OD}_{595} \mathrm{~nm}$ in a microtitre plate reader (iMark, Bio-Rad, Japan). The concentration at which the formation of biofilm is inhibited $\geq 50 \%$ when compared to the untreated control culture is defined as $\mathrm{MBIC}_{50}$ and $\geq 90 \%$ is $\mathrm{MBIC}_{90}$. All the assays were carried out in triplicates.

\section{Anti-virulence Assays}

Among the synthesized compounds, ADM 3 was selected as it showed higher antibiofilm activity at minimal concentration. The compound, ADM 3 was tested against the clinical isolate of $S$. aureus with two sub-MBIC ${ }_{50}$ concentrations (i.e., $1 / 4 \times$ $\left.\mathrm{MBIC}_{50}, 1 / 2 \times \mathrm{MBIC}_{50}\right)$ and at a higher $\mathrm{MBIC}_{50}$ concentration $\left(2 \times \mathrm{MBIC}_{50}\right)$. S. aureus reference strain, untreated with ADM 3 was kept as control. After $24 \mathrm{~h}$, the cultures were centrifuged at $6000 \mathrm{rpm}$ for $10 \mathrm{~min}$ at $4^{\circ} \mathrm{C}$ and filter sterilized in a $0.22 \mu \mathrm{m}$ filter paper to collect the cell free supernatant. The collected supernatant was stored at $4^{\circ} \mathrm{C}$ and further used to quantify hemolysin and protease (Pietrow et al., 2013) among the various secreted exotoxins by $S$. aureus.

\section{Hemolytic Assay}

Hemolysin in the culture supernatant was quantified according to the procedure described earlier with slight modifications 
(Cheung and Otto, 2012). Briefly, $10 \mathrm{~mL}$ of sheep blood was centrifuged at $2400 \mathrm{rpm}$ for $5 \mathrm{~min}$ and the pellet obtained was washed twice with $10 \mathrm{~mL}$ of PBS. Ten microliters of this erythrocyte suspension was incubated with the cell free supernatant for $1 \mathrm{~h}$ at $37^{\circ} \mathrm{C}$. Finally, the incubated sample was centrifuged at $2400 \mathrm{rpm}$ for $5 \mathrm{~min}$. Erythrocyte suspension treated with $1 \%$ Triton $\mathrm{X}-100$ was used as a positive control. The optical density of the supernatant was read at $540 \mathrm{~nm}$. Water along with the erythrocyte suspension was considered as blank. The percentage (\%) hemolysis was calculated using the following formula:

\%Hemolysis = absorbance (sample) - absorbance (blank) $/$ absorbance (positive control)

\section{Proteolysis Assay}

Quantitative estimation of the protease was carried out with azocasein assay. A total of $200 \mu \mathrm{L}$ of the cell free supernatant was incubated with $800 \mu \mathrm{L}$ of azocasein for $30 \mathrm{~min}$ at $37^{\circ} \mathrm{C}$. To this, $1200 \mu \mathrm{L}$ of $1 \%$ trichloroacetic acid was added to arrest the enzymatic reaction. The contents were incubated on ice for $30 \mathrm{~min}$ and centrifuged at $12,000 \mathrm{rpm}$ for $5 \mathrm{~min}$. To $1600 \mu \mathrm{L}$ of the supernatant $400 \mu \mathrm{L}$ of $1.8 \mathrm{~N} \mathrm{NaOH}$ was added and the optical density was read at $420 \mathrm{~nm}$ against the blank (azocasein $+\mathrm{TCA}+\mathrm{NaOH})$. The amount of enzyme required to digest $1 \mathrm{mg}$ of azocasein per minute is known as 1 unit of protein activity (Pietrow et al., 2013). The percentage (\%) proteolysis was calculated using the following formula:

$$
\text { \%Proteolysis = absorbance (sample) }- \text { absorbance (blank) } /
$$
absorbance (control)

\section{Appraisal of the Therapeutic Challenge of ADM 3 on S. aureus Using an In Vitro Catheter Model}

An in vitro catheter model was used to evaluate the effect of ADM 3 on biofilm formation in hydrodynamic conditions (Hancock et al., 2010). Silicone catheter segments of $20 \mathrm{~mm}$ length were cut vertically into two halves, sterilized in $0.5 \%$ sodium hypochlorite solution followed by washing with sterilized water. The sterilized catheters were placed in a six-well microtitre plate and the surface was coated with human blood plasma by incubation at $37^{\circ} \mathrm{C}$ for $24 \mathrm{~h}$. Subsequently, the plasma was removed from the wells and the coated catheters were subjected for the establishment of $S$. aureus infection followed by treatment with $\mathrm{ADM} 3$ for 7 days with concentrations of $1 / 4 \times \mathrm{MBIC}_{50}, 1 / 2 \times \mathrm{MBIC}_{50}, \mathrm{MBIC}_{50}$, and $2 \times \mathrm{MBIC}_{50}$. The plates were incubated at $37^{\circ} \mathrm{C}$ for $24 \mathrm{~h}$ with shaking at $120 \mathrm{rpm}$. After $24 \mathrm{~h}$ of incubation, the medium was changed along with a fresh dosage of the drug each time and this was repeated for 7 days. Also, at every $24 \mathrm{~h}$ interval, the catheters from the wells were removed and analyzed for the viability of cells (Weiss et al., 2009). Briefly, the viability of cells from the catheters was processed by immersing the catheters individually into sterile PBS and followed by sonication. The adherent cells recovered in PBS were plated for colony count in TSB agar plates. Microscopy imaging was used to visually analyze the effect of ADM 3 on biofilm removal. The cells were stained with fluorescein isothiocyanate $(5 \mathrm{mg} / \mathrm{mL})$ and ethidium bromide $(1.25 \mathrm{mg} / \mathrm{mL})$ prepared by mixing $5 \mu \mathrm{L}$ each of the dyes in $1 \mathrm{~mL}$ of cold $0.9 \% \mathrm{NaCl}$ solution. The samples were incubated for $10 \mathrm{~min}$, and then the excess dye was removed by washing with $0.9 \% \mathrm{NaCl}$. All the stained samples were imaged using Olympus FV 1000 confocal microscope with a $10 \times$ objective of numerical aperture 0.3 . The stained samples were excited at $488 \mathrm{~nm}$ using Multi Argon LASER and images were collected from four randomly chosen spots from the sample surface.

\section{Cytotoxicity Analysis of ADM 3 on HEp-2 Cells}

Cell viability was assessed by MTT assay. The reduction of MTT is catalyzed by mitochondrial dehydrogenase enzymes and thus considered to be a measure of cell viability. HEp-2 cells were seeded to each well in a 96-well microtiter plate $\left(1 \times 10^{5}\right.$ cells), in $100 \mu \mathrm{L}$ of DMEM growth medium and the plate was incubated at $37^{\circ} \mathrm{C}$ for $24 \mathrm{~h}$. After incubation, the fresh growth medium was replaced in the wells. ADM 3 was diluted from an original stock to obtain a concentration of $200 \mu \mathrm{g} / \mathrm{mL}$. The HEp- 2 cells were incubated with ADM 3 and allowed to adhere for a period of $72 \mathrm{~h}$. A total of $10 \mu \mathrm{L}$ of MTT solution $(5 \mathrm{mg} / \mathrm{mL}$ in $1 \times \mathrm{PBS})$ was added to each well and the plate was incubated in dark for $4 \mathrm{~h}$ at $37^{\circ} \mathrm{C}$. Further, the content of the each well was removed and the formazan crystals were dissolved in $200 \mu \mathrm{L}$ of dimethyl sulfoxide (DMSO) solution per well. The absorbance was measured at $590 \mathrm{~nm}$ using ELISA plate reader. Only the interior rows of the microtiter plate were used for these experiments to minimize the variations in cell viability due to medium evaporation at the periphery site. The percentage cell viability was calculated with reference to the untreated control cells. The experiment was conducted twice in quadruplicates.

$$
\begin{aligned}
& \text { Percentage cell viability } \\
& \qquad=\frac{\text { OD of drug treated sample }- \text { OD of blank }}{\text { OD of control - OD of blank }} \times 100
\end{aligned}
$$

\section{Statistical Analysis}

Graph pad prism software (version 6.01) was used for statistical analysis. One-way ANOVA and multiple comparisons were done. The minimum level of significance was set at $P \leq 0.05$. All the assays were conducted in triplicates and the results were expressed as mean $\pm \mathrm{SD}$.

\section{RESULTS}

\section{Synthesis of Acyclic Amines and Diamines}

The spectral data of all the synthesized compounds were in full agreement with the proposed structures (Supplementary 
Table S1). The ${ }^{1} \mathrm{H}-\mathrm{NMR}$ data for the synthesized compounds are given below.

AAM 1: $N$-(naphthalene-2-ylmethyl)butan-1-amine

Isolated yield $=78 \%,{ }^{1} \mathrm{H}$ NMR $\left(300 \mathrm{MHz}, \mathrm{CDCl}_{3}\right) \delta 8.12(\mathrm{~d}$, $J=8.3 \mathrm{~Hz}, 1 \mathrm{H}), 7.90-7.83(\mathrm{~m}, 1 \mathrm{H}), 7.77(\mathrm{~d}, J=7.9 \mathrm{~Hz}, 1 \mathrm{H})$, 7.59-7.38 (m, 4H), $4.24(\mathrm{~s}, 2 \mathrm{H}), 2.81-2.71(\mathrm{~m}, 2 \mathrm{H}), 1.61(\mathrm{~s}, 1 \mathrm{H})$, $1.52(\mathrm{dd}, J=8.2,6.1 \mathrm{~Hz}, 2 \mathrm{H}), 1.38(\mathrm{dq}, J=14.1,7.1 \mathrm{~Hz}, 2 \mathrm{H}), 0.93$ (t, $J=7.3 \mathrm{~Hz}, 3 \mathrm{H})$.

AAM 2: ( $N$-benzylbutan-1-amine)

Isolated yield $=55 \%,{ }^{1} \mathrm{H}$ NMR $\left(300 \mathrm{MHz}, \mathrm{CDCl}_{3}\right) \delta 7.38-7.19$ $(\mathrm{m}, 5 \mathrm{H}), 3.79(\mathrm{~s}, 2 \mathrm{H}), 2.63(\mathrm{t}, J=7.2 \mathrm{~Hz}, 2 \mathrm{H}), 1.76(\mathrm{~s}, 1 \mathrm{H}), 1.50$ $(\mathrm{dt}, J=14.4,7.0 \mathrm{~Hz}, 2 \mathrm{H}), 1.40-1.24(\mathrm{~m}, 2 \mathrm{H}), 0.91(\mathrm{t}, J=7.2 \mathrm{~Hz}$, $3 \mathrm{H})$.

\section{AAM 3: ( $N$-benzylcyclohexanamine)}

Isolated yield $=71 \%,{ }^{1} \mathrm{H} \mathrm{NMR}\left(300 \mathrm{MHz}, \mathrm{CDCl}_{3}\right) \delta 7.36-7.22$ (m, 5H), 3.81 (s, 2H), 2.53-2.44 (m, 1H), 1.31-1.06 (m, 11H).

\section{AAM 4: 4(N-(4-methoxybenzyl)butan-1-amine)}

Isolated yield $=65 \%,{ }^{1} \mathrm{H} \mathrm{NMR}\left(300 \mathrm{MHz}, \mathrm{CDCl}_{3}\right) \delta 7.28-7.22$ (m, 2H), $6.91-6.81(\mathrm{~m}, 2 \mathrm{H}), 3.79(\mathrm{~s}, 3 \mathrm{H}), 3.74(\mathrm{~s}, 2 \mathrm{H}), 2.66-2.58$ (m, 2H), 2.49 (s, 1H), 1.52 (ddd, $J=14.4,8.3,5.9 \mathrm{~Hz}, 2 \mathrm{H}), 1.34$ (dd, $J=15.1,7.4 \mathrm{~Hz}, 2 \mathrm{H}), 0.90(\mathrm{t}, J=7.3 \mathrm{~Hz}, 3 \mathrm{H})$.

\section{AAM 5: ( $N$-(4-chlorobenzyl)butan-1-amine)}

Isolated yield $=73 \%,{ }^{1} \mathrm{H} \mathrm{NMR}\left(300 \mathrm{MHz}, \mathrm{CDCl}_{3}\right) \delta 7.33-7.21$ (m, 4H), 3.75 (s, 2H), 2.64-2.57 (m, 2H), 1.68 (s, 1H), 1.55-1.43 $(\mathrm{m}, 2 \mathrm{H}), 1.40-1.27(\mathrm{~m}, 2 \mathrm{H}), 0.91(\mathrm{t}, J=7.3 \mathrm{~Hz}, 3 \mathrm{H})$.

ADM 1: 2,2 ${ }^{1}-(($ Ethane-1,2-diylbis(azanediyl)bis(methylene)) diphenol

Yield 72\%, ${ }^{1} \mathrm{H}-\mathrm{NMR}$ (DMSO-d 6 , $300 \mathrm{MHz}$ ): $\delta 2.51$ (s, 4H), 3.79 (s, 4H), 6.68-6.73 (m, 4H), 7.03-7.08 (m, 4H).

ADM 2: 2,2'-((Propane-1,3-diylbis(azanediyl)bis(methylene)) diphenol

Yield 79\%, ${ }^{1} \mathrm{H}-\mathrm{NMR}$ (DMSO- $\mathrm{d}_{6}, 300 \mathrm{MHz}$ ): $\delta 1.63$ (quin, $J=6.9 \mathrm{~Hz}, 2 \mathrm{H}), 2.55(\mathrm{t}, J=6.9 \mathrm{~Hz}, 4 \mathrm{H}), 3.80(\mathrm{~s}, 4 \mathrm{H}), 6.67-6.72$ (m, 4H), 7.03-7.08 (m, 4H).

ADM 3: 2,2 $2^{1}$-((Butane-1,4-diylbis(azanediyl)bis(methylene)) diphenol

Yield 69\%, ${ }^{1} \mathrm{H}-\mathrm{NMR}$ (DMSO-d $\mathrm{d}_{6}, 300 \mathrm{MHz}$ ): $\delta 1.47$ (s, 4H), 2.50 $(\mathrm{q}, J=1.8 \mathrm{~Hz}, 4 \mathrm{H}), 3.81(\mathrm{~s}, 4 \mathrm{H}), 6.66-6.72(\mathrm{~m}, 4 \mathrm{H}), 7.03-7.09(\mathrm{~m}$, $4 \mathrm{H})$.

ADM 4: $\mathrm{N}^{1}, \mathrm{~N}^{2}$-dibenzylethane-1,2-diamine

Yield 82\%, ${ }^{1} \mathrm{H}-\mathrm{NMR}$ (DMSO- $\mathrm{d}_{6}, 300 \mathrm{MHz}$ ): $\delta 2.51$ (s, 4H), 3.66 (s, 4H), 7.20-7.32 (m, 10H).

ADM 5: $\mathrm{N}^{1}, \mathrm{~N}^{2}$-dibenzylpropane-1, 3-diamine

Yield 73\%, ${ }^{1} \mathrm{H}-\mathrm{NMR}\left(\mathrm{CDCl}_{3}, 300 \mathrm{MHz}\right): \delta 1.72$ (quin, $J=6.9 \mathrm{~Hz}$, $2 \mathrm{H}), 2.69(\mathrm{t}, J=6.9 \mathrm{~Hz}, 4 \mathrm{H}), 3.77(\mathrm{~s}, 4 \mathrm{H}), 7.24-7.32(\mathrm{~m}, 10 \mathrm{H})$.

ADM 6: $\mathrm{N}^{1}, \mathrm{~N}^{2}$-bis(naphthalene-2-ylmethyl)ethane-1,2diamine

Yield 76\%, ${ }^{1} \mathrm{H}-\mathrm{NMR}$ (DMSO-d $\mathrm{d}_{6}, 300 \mathrm{MHz}$ ): $\delta 2.75$ (s, 4H), 4.11 (s, 4H), 7.40-7.52 (m, 8H), $7.80(\mathrm{~d}, J=7.5 \mathrm{~Hz}, 2 \mathrm{H}), 7.89-7.92(\mathrm{~m}$, $2 \mathrm{H}), 8.13-8.17(\mathrm{~m}, 2 \mathrm{H})$.
TABLE 2 | Antimicrobial and antibiofilm values of acyclic amines and diamines.

\begin{tabular}{lcccc}
\hline Compound & MIC $(\mu \mathbf{g} / \mathbf{m L})$ & MBC $(\mu \mathbf{g} / \mathbf{m L})$ & \multicolumn{2}{c}{ MBIC $(\mu \mathbf{g} / \mathbf{m L})$} \\
\cline { 4 - 5 } & & & 50 & $\mathbf{9 0}$ \\
\hline AAM 1 & 200 & 200 & - & - \\
AAM 2 & 200 & 200 & - & - \\
AAM 3 & - & - & - & - \\
AAM 4 & 100 & 200 & - & - \\
AAM 5 & - & 200 & - & - \\
ADM 1 & 200 & 200 & - & - \\
ADM 2 & - & 50 & 10 & - \\
ADM 3 & 50 & 200 & 5 & - \\
ADM 4 & - & - & 25 & - \\
ADM 5 & - & 200 & 20 & - \\
ADM 6 & - & - & 40 & - \\
ADM 7 & - & - & 40 & - \\
ADM 8 & 150 & - & - & - \\
& & & & - \\
& & & &
\end{tabular}

ADM 7: $N^{1}, N^{3}$-bis(naphthalene-2-ylmethyl)propane-1,3diamine

Yield 78\%, ${ }^{1} \mathrm{H}-\mathrm{NMR}\left(\mathrm{CDCl}_{3}, 300 \mathrm{MHz}\right): \delta 1.61(\mathrm{t}, J=6.3 \mathrm{~Hz}$, $4 \mathrm{H}), 2.76(\mathrm{t}, J=6.3 \mathrm{~Hz}, 4 \mathrm{H}), 4.22(\mathrm{~s}, 4 \mathrm{H}), 7.41-7.55(\mathrm{~m}, 8 \mathrm{H}), 7.76$ $(\mathrm{d}, J=7.5 \mathrm{~Hz}, 2 \mathrm{H}), 7.86(\mathrm{~d}, J=7.5 \mathrm{~Hz}, 2 \mathrm{H}), 8.10(\mathrm{~d}, J=7.8 \mathrm{~Hz}$, $2 \mathrm{H})$.

ADM 8: $\mathrm{N}^{1}$-(naphthalene-2-yl)- $\mathrm{N}^{4}$-(naphthalene-2-ylmethyl) butane-1,4-diamine

Yield 80\%, ${ }^{1} \mathrm{H}-\mathrm{NMR}$ (DMSO- $\mathrm{d}_{6}, 300 \mathrm{MHz}$ ): $\delta 1.83$ (quin, $J=6.9 \mathrm{~Hz}, 2 \mathrm{H}), 2.83(\mathrm{t}, J=6.9 \mathrm{~Hz}, 4 \mathrm{H}), 4.21(\mathrm{~s}, 4 \mathrm{H}), 7.37-$ $7.52(\mathrm{~m}, 8 \mathrm{H}), 7.76(\mathrm{dd}, J=7.5,1.8 \mathrm{~Hz}, 2 \mathrm{H}), 7.85-7.88(\mathrm{~m}, 2 \mathrm{H})$, $8.07-8.11(\mathrm{~m}, 2 \mathrm{H})$.

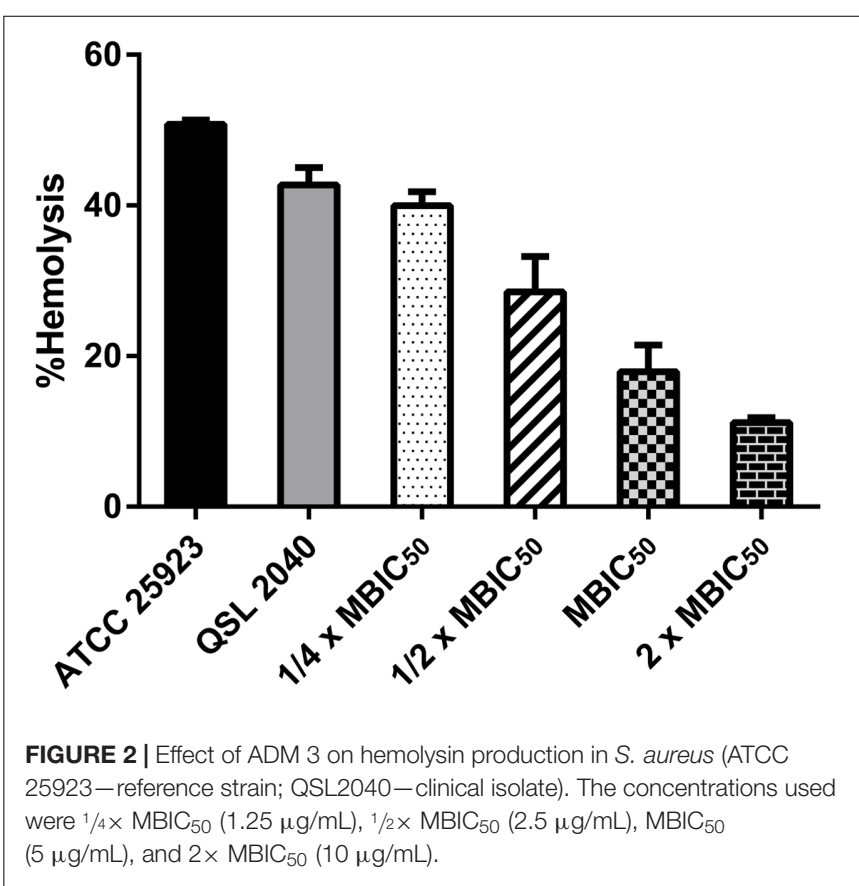




\section{Antimicrobial and Antibiofilm Activity of Acyclic Amines and Diamines}

The MICs, MBCs, and MBICs of acyclic amines and diamines were shown in Table 2. In general, acyclic amines were found to have high MIC and MBC values but no antibiofilm activity. Alternatively, the acyclic diamine compounds, particularly ADM 3 was observed to exhibit good antimicrobial as well as antibiofilm activity. The concentration of antimicrobial and antibiofilm activity of ADM 3 was found to be 50 and $5 \mu \mathrm{g} / \mathrm{mL}$ $\left(\mathrm{MBIC}_{50}\right)$ respectively. The biofilm inhibitory concentration for compound ADM 3 was found to be 10 -fold lesser than the MIC. Thus, compound ADM 3 acts as a potential antibacterial as well as antibiofilm agent and was considered for further studies.

\section{Anti-virulence Assays}

Percentage hemolysis and proteolysis by ADM 3 on S. aureus clinical isolate, MDRSA - QSL2040 are shown in Figures 2, 3 respectively. ADM 3 exhibited a similar effect on protease as well as on hemolysin production and a dose-dependent reduction was observed in both the cases. Clinical isolate (MDRSA QSL2040) treated with ADM 3 showed a significant reduction in proteolytic and hemolytic activity when compared with the untreated control.

\section{In Vitro Catheter Model}

Live dead staining of $S$. aureus in the presence and absence of ADM 3 revealed that, ADM 3 treatment induced significant loss of viability and colonization of biofilm on catheters as evidenced by the red fluorescence observed in treated samples at day 7 . All the captured images were uniform and a representative image is shown in Figure 4. Thus, in consonance with our antibiofilm results in microtitre plate experiments, ADM 3 was effective in inhibition of $S$. aureus biofilm in catheters. The treatment of these catheters showed a decrease in the cell count from day 4 onward compared to untreated control (Supplementary Figure S1).

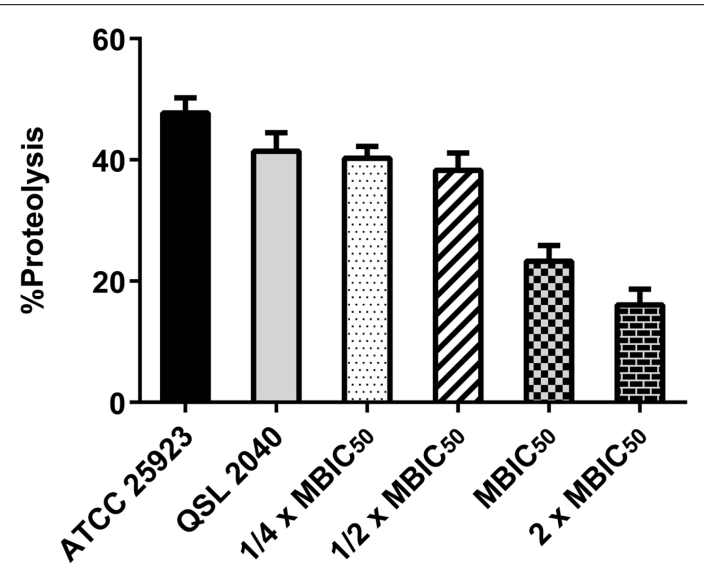

FIGURE 3 | Effect of ADM 3 on protease production in S. aureus (ATCC 25923-reference strain; QSL2040 - clinical isolate). The concentrations used were $1 / 4 \times \mathrm{MBIC}_{50}(1.25 \mu \mathrm{g} / \mathrm{mL}), 1 / 2 \times \mathrm{MBIC}_{50}(2.5 \mu \mathrm{g} / \mathrm{mL}), \mathrm{MBIC}_{50}$ $(5 \mu \mathrm{g} / \mathrm{mL})$, and $2 \times \mathrm{MBIC}_{50}(10 \mu \mathrm{g} / \mathrm{mL})$.

\section{Cytotoxicity Analysis on HEp-2 Cell Lines}

Percentage cell viability of each experimental group was calculated with reference to the untreated control cells and it was observed that cell viability was higher than $85 \%$ in all drug doses (Figure 5). Statistical analysis was performed using the one way ANOVA and $P \leq 0.001$ was considered significant.

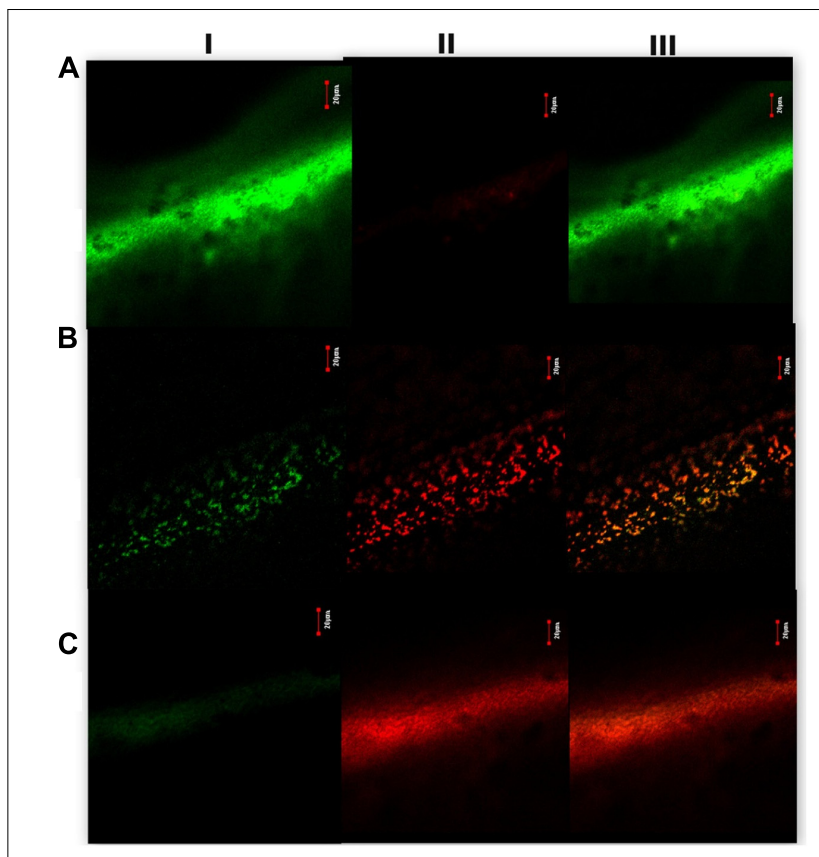

FIGURE 4 | Confocal laser scanning microscope images of biofilm formed on urinary catheters. I-FITC labeled (green/viable cells); II-ethidium bromide labeled (red/non-viable cells); and III-superimposed images of I and II. (A) Control, untreated with ADM 3, (B) treated with ADM $3\left(\mathrm{MBIC}_{50}\right.$ at $5 \mu \mathrm{g} / \mathrm{mL})$, and $(\mathbf{C})$ treated with $\mathrm{ADM}_{3}\left(2 \times \mathrm{MBIC}_{50}\right.$ at $\left.10 \mu \mathrm{g} / \mathrm{mL}\right)$.

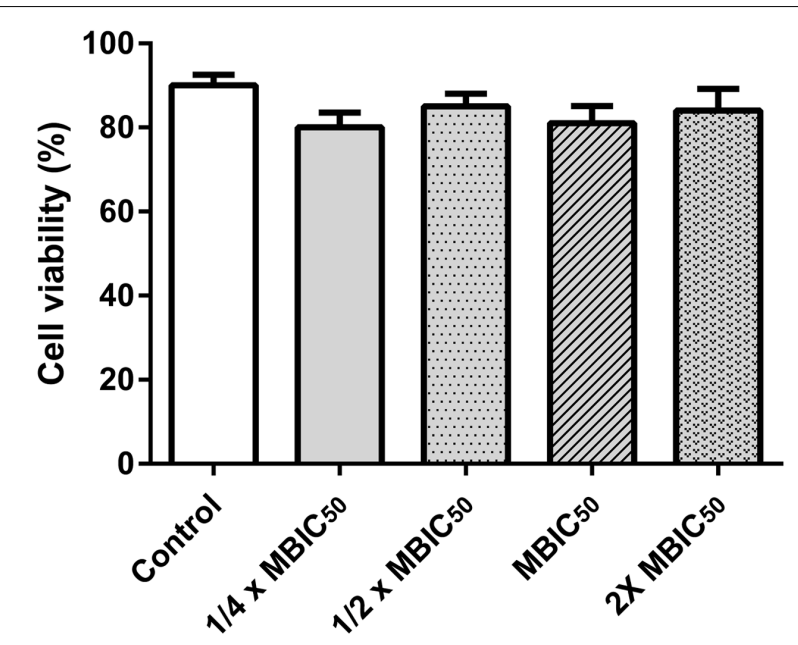

FIGURE 5 | Effect of ADM 3 on HEp-2 cell lines for cell viability by MTT assay. The concentrations used were $1 / 4 \times \mathrm{MBIC}_{50}(1.25 \mu \mathrm{g} / \mathrm{mL}), 1 / 2 \times \mathrm{MBIC}_{50}$ $(2.5 \mu \mathrm{g} / \mathrm{mL}), \mathrm{MBIC}_{50}(5 \mu \mathrm{g} / \mathrm{mL})$, and $2 \times \mathrm{MBIC}_{50}(10 \mu \mathrm{g} / \mathrm{mL})$. 


\section{DISCUSSION}

The key consequences of biofilm based infections are resistant to antibiotics as well as many other conventional antimicrobial agents. This eventually leads to the development of MDR pathogens with an extreme capacity for evading the host defense mechanisms. It is well known that bacterial biofilm exhibits antibiotic diffusion barrier (Cloete, 2003). In such cases, a large portion of the cells embedded in biofilms might escape from both antibiotic treatments as well as host's immune system responses. Such bacterial cells lead to the replenishment of biofilm at a new site causing are occurrence of infection with high resistance to antibiotics. Consequently, it becomes difficult to treat the infection using bactericidal drugs via systemic administration and demands the need for the evaluation of novel antibiofilm drugs. As an alternative to conventional antibiotic therapy and to control MDR, we hereby report a series of acyclic amines and diamines as potential drug candidates in the light of our earlier studies (Arya and Princy, 2013; Balamurugan et al., 2017). Among these, ADM 3 (2,2'-((butane-1,4-diylbis(azanediyl)bis(methylene))diphenol) showed a significant reduction in bacterial cell count as well as biofilm inhibition.

Targeting virulence factors in bacteria is an alternative approach to antimicrobial therapy that offers promising insights and opportunities to inhibit bacterial pathogenesis (Kauppi et al., 2003; Åberg and Almqvist, 2007). Certain virulence factors have been shown as potential leads for drug design and therapeutic intervention, whereas new possible insights are crucial for exploring others (Projan, 2002). Among the various virulence factors expressed in $S$. aureus, protease, as well as hemolysin production, plays a crucial role in the interaction of bacteria with the host cell for establishing an infection (Kupferwasser et al., 2003). In the present study, ADM 3 that showed effective $\mathrm{MBIC}_{50}$ and $\mathrm{MIC}$ was also effective in reducing protease as well as hemolysin production.

In vitro catheter model showed decreased biofilm as well as increased red fluorescence in the confocal laser scanning microscope images at day 7. This suggests that ADM 3 has both antimicrobial and antibiofilm activities. In addition, decreased cell count observed after day 4 till the experimental study period also suggests the potential of ADM 3. This implies that the ADM 3 was proven to show a potent biofilm inhibiting agent as well as an antimicrobial agent. It is already shown through our in silico

\section{REFERENCES}

Abad, C. L., Pulia, M. S., Krupp, A., and Safdar, N. (2014). Reducing transmission of methicillin-resistant Staphylococcus aureus and vancomycinresistant Enterococcus in the ICU-an update on prevention and infection control practices. JCOM 21, 218-232.

Abdel-Rahman, A. H., Keshk, E. M., Hanna, M. A., and El-Bady, S. M. (2004). Synthesis and evaluation of some new spiro indoline-based heterocycles as potentially active antimicrobial agents. Bioorg. Med. Chem. 12, 2483-2488. doi: 10.1016/j.bmc.2003.10.063

Åberg, V., and Almqvist, F. (2007). Pilicides-small molecules targeting bacterial virulence. Org. Biomol. Chem. 5, 1827-1834. doi: 10.1039/B702 $397 \mathrm{~A}$ studies that the hydroxyl and amine groups of the compound SarABI-12, interact with the oxygen atoms of E89 and R90 of SarA protein respectively, to form hydrogen bonds (Arya and Princy, 2013). Moreover, our in vitro studies also have confirmed the antibiofilm activities by the target specific interaction with SarA, which is a quorum regulator of $S$. aureus. Since ADM 3 is a derivative of SarABI-12, which carries both the hydroxyl and amine groups, it is speculated that the biofilm inhibition activity also could be of the similar mechanism.

Furthermore, a therapeutic molecule should not have cytotoxic effects if it has to be taken for further clinical trials. Generally, a compound is usually considered to have in vitro cytotoxicity if the particular concentration of the drug causes a $50 \%$ cell killing. Our data suggest that the compound ADM 3 may act as a potential drug which does not cause any cytotoxicity. To the best of our knowledge, our study is the first to report the antimicrobial and antibiofilm activity of acyclic amines and diamines. Our data also provide an insight that these compounds can act as a potential drug candidate to treat MDRSA. It would be interesting to explore the activity of these organic molecules at the molecular level to depict their mode of action involved in antibiofilm and antibacterial activity.

\section{AUTHOR CONTRIBUTIONS}

All authors listed have made a substantial, direct and intellectual contribution to the work, and approved it for publication.

\section{ACKNOWLEDGMENTS}

We sincerely acknowledge the management and Dr. S. Swaminathan, Dean Sponsored Research of SASTRA University for their support and encouragement throughout this project. The authors are also grateful to the TRR in-house funding scheme of SASTRA University for the purchase of consumables.

\section{SUPPLEMENTARY MATERIAL}

The Supplementary Material for this article can be found online at: http://journal.frontiersin.org/article/10.3389/fmicb. 2017.01767/full\#supplementary-material

Arya, R., Kannan, R. V., Shrivastava, S., and Princy, S. (2011). Studies on the effect of amino acids to curb the pathogenesis of multi drug resistant Staphylococcus aureus. Asian J. Chem. 23, 4295-4298.

Arya, R., and Princy, S. (2013). Computational approach to design small molecule inhibitors and identify SarA as a potential therapeutic candidate. Med. Chem. Res. 22, 1856-1865. doi: 10.1007/s00044-012-0185-9

Balamurugan, P., Praveen Krishna, V., Bharath, D., Lavanya, R., Vairaprakash, P., and Adline Princy, S. (2017). Staphylococcus aureus quorum regulator SarA targeted compound, 2-[(Methylamino)methyl]phenol inhibits biofilm and down-regulates virulence genes. Front. Microbiol. 8:1290. doi: 10.3389/fmicb. 2017.01290

Bascones-Martinez, A., Matesanz-Perez, P., Escribano-Bermejo, M., GonzalezMoles, M. A., Bascones-Ilundain, J., and Meurman, J. H. (2011). Periodontal 
disease and diabetes-review of the Literature. Med. Oral Patol. Oral Cir. Bucal 16, e722-e729. doi: 10.4317/medoral.17032

Becker, K., Friedrich, A. W., Lubritz, G., Weilert, M., Peters, G., and Von Eiff, C. (2003). Prevalence of genes encoding pyrogenic toxin superantigens and exfoliative toxins among strains of Staphylococcus aureus isolated from blood and nasal specimens. J. Clin. Microbiol. 41, 1434-1439. doi: 10.1128/JCM.41.4. 1434-1439.2003

Cheung, G. Y. C., and Otto, M. (2012). The potential use of toxin antibodies as a strategy for controlling acute Staphylococcus aureus infections. Expert Opin. Ther. Targets 16, 601-612. doi: 10.1517/14728222.2012.682573

Chtchigrovsky, M., Eloy, L., Jullien, H., Saker, L., Ségal-Bendirdjian, E., Poupon, J., et al. (2013). Antitumor trans-N-heterocyclic carbene-amine-Pt(II) complexes: synthesis of dinuclear species and exploratory investigations of DNA binding and cytotoxicity mechanisms. J. Med. Chem. 56, 2074-2086. doi: 10.1021/ jm301780s

Cloete, T. E. (2003). Resistance mechanisms of bacteria to antimicrobial compounds. Int. Biodeterior. Biodegradation 51, 277-282. doi: 10.1016/S09648305(03)00042-8

Cole, A. M., Tahk, S., Oren, A., Yoshioka, D., Kim, Y.-H., Park, A., et al. (2001). Determinants of Staphylococcus aureus nasal carriage. Clin. Diagn. Lab. Immunol. 8, 1064-1069. doi: 10.1128/CDLI.8.6.1064-1069.2001

Dinges, M. M., Orwin, P. M., and Schlievert, P. M. (2000). Exotoxins of Staphylococcus aureus. Clin. Microbiol. Rev. 13, 16-34. doi: 10.1128/CMR.13. 1.16-34.2000

Fedtke, I., Götz, F., and Peschel, A. (2004). Bacterial evasion of innate host defenses-the Staphylococcus aureus lesson. Int. J. Med. Microbiol. 294, 189-194. doi: 10.1016/j.ijmm.2004.06.016

Flemming, H.-C., Neu, T. R., and Wozniak, D. J. (2007). The EPS matrix: the house of biofilm cells. J. Bacteriol. 189, 7945-7947. doi: 10.1128/JB.00858-07

Hancock, V., Dahl, M., and Klemm, P. (2010). Abolition of biofilm formation in urinary tract Escherichia coli and Klebsiella isolates by metal interference through competition for fur. Appl. Environ. Microbiol. 76, 3836-3841. doi: 10.1128/AEM.00241-10

He, Y., Wu, B., Yang, J., Robinson, D., Risen, L., Ranken, R., et al. (2003). 2-Piperidin-4-yl-benzimidazoles with broad spectrum antibacterial activities. Bioorg. Med. Chem. Lett. 13, 3253-3256. doi: 10.1016/S0960-894X(03)00661-9

Hensler, M. E., Bernstein, G., Nizet, V., and Nefzi, A. (2006). Pyrrolidine bis-cyclic guanidines with antimicrobial activity against drug-resistant Gram-positive pathogens identified from a mixture-based combinatorial library. Bioorg. Med. Chem. Lett. 16, 5073-5079. doi: 10.1016/j.bmcl.2006.07.037

Issam, A.-A., Zimmermann, S., Reichling, J., and Wink, M. (2015). Pharmacological synergism of bee venom and melittin with antibiotics and plant secondary metabolites against multi-drug resistant microbial pathogens. Phytomedicine 22, 245-255. doi: 10.1016/j.phymed.2014.11.019

Juranić, I. O., Tošić, A. V., Kolundžija, B., and Drakuliæ, B. J. (2014). Antiproliferative activity of the Michael adducts of aroylacrylic acids and cyclic amines. Mol. Divers. 18, 577-592. doi: 10.1007/s11030-014-9528-4

Kauppi, A. M., Nordfelth, R., Uvell, H., Wolf-Watz, H., and Elofsson, M. (2003). Targeting bacterial virulence: inhibitors of type III secretion in Yersinia. Chem. Biol. 10, 241-249. doi: 10.1016/S1074-5521(03)00046-2

Kazakova, O. B., Giniyatullina, G. V., Medvedeva, N. I., Lopatina, T. V., Baikova, I. P., Tolstikov, G. A., et al. (2014). Synthesis and cytotoxicity of triterpene seven-membered cyclic amines. Russ. J. Bioorganic Chem. 40, 198-205. doi: $10.1134 /$ S106816201402006X

Khatkar, A., Nanda, A., Kumar, P., and Narasimhan, B. (2014). Synthesis, antimicrobial evaluation and QSAR studies of p-coumaric acid derivatives. Arab. J. Chem. 10, S3804-S3815. doi: 10.1016/j.arabjc.2014.05.018

Kluytmans, J., Van Belkum, A., and Verbrugh, H. (1997). Nasal carriage of Staphylococcus aureus: epidemiology, underlying mechanisms, and associated risks. Clin. Microbiol. Rev. 10, 505-520.

Kumar, M., Narasimhan, B., Ramasamy, K., Mani, V., Mishra, R. K., and Majeed, A. B. A. (2013). Synthesis, antimicrobial and cytotoxic evaluation of 4-(1-aryl-5-halo-2-oxo-1, 2-dihydro-indol-3-ylideneamino)$\mathrm{N}$-substituted benzene sulphonamides. Arab. J. Chem. 10, S2845-S2852. doi: 10.1016/j.arabjc.2013.11.009

Kupferwasser, L. I., Yeaman, M. R., Nast, C. C., Kupferwasser, D., Xiong, Y.-Q., Palma, M., et al. (2003). Salicylic acid attenuates virulence in endovascular infections by targeting global regulatory pathways in Staphylococcus aureus. J. Clin. Invest. 112, 222-233. doi: 10.1172/JCI200316876

Otto, M. (2013). Staphylococcal infections: mechanisms of biofilm maturation and detachment as critical determinants of pathogenicity. Annu. Rev. Med. 64, 175-188. doi: 10.1146/annurev-med-042711-140023

Parsek, M., and Singh, P. (2003). Bacterial biofilms: an emerging link to disease pathogenesis. Annu. Rev. Microbiol. 57, 677-701. doi: 10.1146/annurev.micro. 57.030502 .090720

Pietrow, O., Panek, A., and Synowiecki, J. (2013). Extracellular proteolytic activity of Deinococcus geothermalis. Afr. J. Biotechnol. 12, 4020-4027.

Projan, S. J. (2002). New (and not so new) antibacterial targets-from where and when will the novel drugs come? Curr. Opin. Pharmacol. 2, 513-522. doi: 10.1016/S1471-4892(02)00197-2

Qayyum, S., Sharma, D., Bisht, D., and Khan, A. U. (2016). Protein translation machinery holds a key for transition of planktonic cells to biofilm state in Enterococcus faecalis: a proteomic approach. Biochem. Biophys. Res. Commun. 474, 652-659. doi: 10.1016/j.bbrc.2016.04.145

Ramachandran, P., Gagare, P., Sakavuyi, K., and Clark, P. (2010). Reductive amination using ammonia borane. Tetrahedron Lett. 51, 3167-3169. doi: 10.1016/j.tetlet.2010.04.014

Ravichandiran, V., Shanmugam, K., Anupama, K., Thomas, S., and Princy, A. (2012). Structure-based virtual screening for plant-derived SdiA-selective ligands as potential antivirulent agents against uropathogenic Escherichia coli. Eur. J. Med. Chem. 48, 200-205. doi: 10.1016/j.ejmech.2011. 12.015

Safdar, N., and Maki, D. G. (2004). The pathogenesis of catheter-related bloodstream infection with noncuffed short-term central venous catheters. Intensive Care Med. 30, 62-67. doi: 10.1007/s00134-003-2045-Z

Singh, P., Schaefer, A., Parsek, M., and Moninger, T. (2000). Quorum-sensing signals indicate that cystic fibrosis lungs are infected with bacterial biofilms. Nature 407, 762-764. doi: 10.1038/35037627

Subík, J., Takácsová, G., Psenák, M., and Devínsky, F. (1977). Antimicrobial activity of amine oxides: mode of action and structure-activity correlation. Antimicrob. Agents Chemother. 12, 139-146. doi: 10.1128/AAC.12.2.139

Vincze, S., Stamm, I., Kopp, P. A., Hermes, J., Adlhoch, C., Semmler, T., et al. (2014). Alarming proportions of methicillin-resistant Staphylococcus aureus (MRSA) in wound samples from companion animals, Germany 2010-2012. PLOS ONE 9:e85656. doi: 10.1371/journal.pone.0085656

Weiss, E. C., Spencer, H. J., Daily, S. J., Weiss, B. D., and Smeltzer, M. S. (2009). Impact of sarA on antibiotic susceptibility of Staphylococcus aureus in a catheter-associated in vitro model of biofilm formation. Antimicrob. Agents Chemother. 53, 2475-2482. doi: 10.1128/AAC.01432-08

Zhu, J., Lu, C., Standland, M., Lai, E., Moreno, G. N., Umeda, A., et al. (2008). Single mutation on the surface of Staphylococcus aureus Sortase A can disrupt its dimerization. Biochemistry 47, 1667-1674. doi: 10.1021/bi7014597

Conflict of Interest Statement: The authors declare that the research was conducted in the absence of any commercial or financial relationships that could be construed as a potential conflict of interest.

Copyright (C) 2017 Kaur, Balamurugan, Vasudevan, Jadav and Princy. This is an open-access article distributed under the terms of the Creative Commons Attribution License (CC BY). The use, distribution or reproduction in other forums is permitted, provided the original author(s) or licensor are credited and that the original publication in this journal is cited, in accordance with accepted academic practice. No use, distribution or reproduction is permitted which does not comply with these terms. 